\title{
An arachidonic acid-preferring acyl-CoA synthetase is a hormone-dependent and obligatory protein in the signal transduction pathway of steroidogenic hormones
}

\author{
Fabiana Cornejo Maciel, Paula Maloberti, Isabel Neuman, Florencia Cano, Rocío Castilla, \\ Fernanda Castillo, Cristina Paz and Ernesto J Podestá
}

Department of Biochemistry, School of Medicine, University of Buenos Aires, Paraguay 2155, $5^{\text {th }}(C 1121$ ABG) Buenos Aires, Argentina

(Requests for offprints should be addressed to F Cornejo Maciel; Email: fcornejo@fmed.uba.ar)

\begin{abstract}
We have described that, in adrenal and Leydig cells, the hormonal regulation of free arachidonic acid (AA) concentration is mediated by the concerted action of two enzymes: an acyl-CoA thioesterase (MTE-I or ARTISt) and an acyl-CoA synthetase (ACS4). In this study we analyzed the potential regulation of these proteins by hormonal action in steroidogenic cells. We demonstrated that ACS4 is rapidly induced by adrenocorticotropin (ACTH) and cAMP in Y1 adrenocortical cells. The hormone and its second messenger increased ACS4 protein levels in a time and concentration dependent way. Maximal concentration of ACTH $(10 \mathrm{mlU} / \mathrm{ml})$ produced a significant effect after $15 \mathrm{~min}$ of treatment and exerted the highest increase (3-fold) after $30 \mathrm{~min}$. Moreover, ${ }^{35} \mathrm{~S}$-methionine incorporation showed that the increase in ACS4 protein levels is due to an increase in the de novo synthesis of the protein. On the contrary MTE-I protein levels in Y1 and MA-10 cells did not change after steroidogenic stimuli. In contrast with the effect observed on protein levels, stimulation of both cell lines did not change ACS4 RNA levels during the first hour of treatment, indicating that the effect of both stimuli is exerted at the level of ACS4 protein synthesis.

StAR protein induction has a key role on the activation of steroidogenesis since this protein increases the rate of the limiting step of the whole process. In agreement with the fact that the inhibition of ACS4 activity by triacsin C blocks CAMP-stimulated progesterone production by MA-10 Leydig cells, here we demonstrated that ACS4 inhibition also reduces StAR protein levels. Moreover, exogenous AA was able to overcome the effect of triacsin $\mathrm{C}$ on both events, StAR induction and steroidogenesis. These results were confirmed by experiments using ACS4-targeted siRNA which result in a reduction in both ACS4 and StAR protein levels. The concomitant decrease in steroid production was overcome by the addition of AA to the knocked-out cells. In summary, this study suggests that in adrenal and Leydig cells the hormonal action prompts the synthesis of a labile protein, ACS4, which activity is involved in the regulation of AA release and is essential for steroidogenesis and StAR protein induction.
\end{abstract}

Journal of Molecular Endocrinology (2005) 34, 655-666

\section{Introduction}

In the different steroidogenic tissues the appropriate trophic hormone activates the mitochondrial conversion of cholesterol to pregnenolone. This reaction is catalyzed by the side-chain splitting cytochrome P450 enzyme (P450 scc) located in the matrix side of the inner mitochondrial membrane. The access of free cholesterol to the active site of P450 scc, and not the enzymatic activity itself, is the true rate-limiting step in immediate steroidogenesis (Crivello \& Jefcoate 1980, Privalle et al. 1983). Numerous reports indicate that this event is controlled by the steroidogenic acute regulatory protein (StAR protein) (Clark et al. 1994, Stocco \& Clark 1996, Wang et al. 2000). In addition, it is well known that steroid biosynthesis requires de novo protein synthesis of a labile factor that has a short half-life, and the process is inhibited by cycloheximide (CHX) (Garren et al. 1965,
Cooke et al. 1975). In this regard, the further characterization of StAR has revealed that this protein may be considered as the 'labile' factor that mediates the steroidogenic response to hormone action in adrenal and Leydig cells, as well as in other steroidogenic systems studied to date. Thus, StAR is rapidly synthesized in response to the respective trophic hormones, it is cycloheximide-sensitive, its active form has a very short half-life and it rapidly increases the transport of cholesterol to the site of P450 scc action (Stocco \& Clark 1996, Reinhart et al. 1999).

In adrenal and Leydig cells, the increase of $3^{\prime}$, $5^{\prime}$-cyclic-adenosine monophosphate (cAMP) levels and cAMP-dependent protein kinase (PKA) phosphorylation events are accepted as intermediate steps in the adrenocorticotropin (ACTH) and luteinizing hormone (LH) action (Dufau et al. 1977, Sala et al. 1979). It is also accepted that cAMP and PKA regulate arachidonic acid 
(AA) release. Following LH stimulation, AA is released within one minute in rat testicular Leydig cells (Dix et al. 1984, Didolkar \& Sundaram 1987, Cooke et al. 1991). Also, AA release occurs in a dose and time dependent manner in human chorionic gonadotropin (hCG)stimulated Leydig (Moraga et al. 1997) and ACTHstimulated adrenal cells (Dada et al. 1996). In addition, previous studies have reported that inhibition of AA release abrogates the effect of LH- (Mele et al. 1997) and ACTH-stimulated steroid production (Solano et al. 1988). Recently, we have presented results suggesting that in steroidogenic tissues the release of $\mathrm{AA}$ involves the action of two enzymes, an acyl-CoA synthetase and an acyl-CoA thioesterase (Finkielstein et al. 1998, Maloberti et al. 2002). The acyl-CoA thioesterase, MTE-I (Svensson et al. 1998) or ARTISt (Finkielstein et al. 1998), is a mitochondrial phosphoprotein included in a family of acyl-CoA thioesterases that displays preferential activity towards very long chain acyl-CoA (Svensson et al. 1998). The protein was first identified by its capacity to increase mitochondrial steroidogenesis in a cell-free assay (Paz et al. 1994). It is present in adrenal and testicular Leydig cells, and ovary, brain and placenta among other tissues (Finkielstein et al. 1996), and its activity would be regulated by ACTH (Maloberti et al. 2002).

The second enzyme involved in AA release in steroidogenic tissues, the acyl-CoA synthetase, is an enzyme designed ACS4 that belongs to a five-member family. ACS4 shares $68 \%$ of its amino acid sequence with ACS3, another member of this family, although this sequence is poorly related to the other family members (Kang et al. 1997). The purified enzyme utilizes arachidonate as substrate most preferentially among other C8-C22 saturated fatty acids and C4-C22 unsaturated fatty acids. The striking feature of ACS4 is its abundance in steroidogenic tissues, especially adrenal gland and ovary. ACS4 immunoreactivity was detected in the zona fasciculata $(\mathrm{ZF})$ and reticularis of the adrenal cortex, in the corpus luteum and stromal luteinized cells of the ovary and in the Leydig cells of the testis (Kang et al. 1997).

Given that AA release is linked to hormonedependent StAR induction and steroidogenesis (Wang et al. 2000), the present study was undertaken to investigate whether $\mathrm{AA}$ release in steroidogenic tissues by hormone action involves the regulation of the levels of the acyl-CoA synthetase and/or thioesterase.

In the present study the results demonstrate that hormone treatment of adrenal and Leydig cells does not modify MTE-I protein levels while it induces ACS4 protein. This enzyme appears rapidly in response to the respective trophic hormone and seems to have a short half-life. The data are consistent with the presence of a new factor, ACS4, which is essential for StAR induction and steroidogenesis.

\section{Materials and methods}

\section{Materials}

ACTH was a kind gift of Elea Laboratories (Buenos Aires, Argentina). Dexamethasone (9-fluoro-11 $\beta, 17,21$ trihydroxy-16 $\alpha$-methyl-pregna-1,4-diene-3,20-dione) was a kind gift from Ciba Geigy (Basel, Switzerland). Media, sera, antibiotics, Trypsin-EDTA, TriZol reagent and Lipofectamine 2000 were from Gibco-Life Technologies (Carlsbad, CA, USA); plastic flasks and dishes were provided by Corning-Costar (Corning, NY, USA). Acrylamide, bis-acrylamide, cycloheximide (CHX), 8Br3', 5'-cyclic-adenosine-monophosphate (8Br-cAMP), arachidonic acid (AA), trypsin from bovine pancreas, soybean trypsin inhibitor, agarose, formaldehyde, bovine seroalbumin (BSA) and fatty acid-free BSA were obtained from Sigma-Aldrich Fine Chemicals (St Louis, MO, USA). Triacsin C was bought from ICN (Aurora, $\mathrm{OH}$, USA). Polyclonal antibodies against MTE-I were previously obtained at our laboratory (Maloberti et al. 2002). Anti-ACS4 antibodies were obtained from immunizing rabbits with recombinant ACS4 protein. The protein was obtained in E.coli (BL21) transfected with a plasmid (pGEX-4T3) containing ACS4 sequence, kindly provided by Dr T Yamamoto (University of Tohoku, Sendai, Japan). In Y1 and MA-10 cells, Western blot analysis utilizing this antiserum results in only one band of the expected molecular weight $(74 \mathrm{kDa})$, which is not detected by pre-immune serum or when the antiserum is pre-adsorbed with the immunogen. Moreover, its specificity is demonstrated by the fact that in adult cardiac tissue, where ACS4 is not expressed, the antibody does not reveal any band, although this tissue expresses ACS3, another synthetase isoform. Anti-StAR antibody was generously provided by Dr Douglas Stocco (Texas Tech University, Lubbock, Texas, USA). Anti- $\beta$-tubulin monoclonal antibody was bought from Upstate (Lake Placid, NY, USA). Electrophoresis supplies, polyvinylidendifluoride membrane and secondary antibody (horseradish peroxidaseconjugated goat antibody) were bought to Bio-Rad Laboratories Inc. (Hercules, CA, USA). ECL kit and Hybond $\mathrm{N}^{+}$membrane were provided by Amersham Pharmacia Biotech (Buckinghamshire, UK). All other chemicals were commercial products of the highest grade available.

\section{Animals}

The use of animals complies with the guidelines approved by the Animal Welfare and Health Committee of the University of Buenos Aires. Male Wistar rats (90-day-old) were used throughout. Adrenal gland or ZF cells were obtained from animals supplied with dexamethasone $(10 \mu \mathrm{g} / \mathrm{ml}$, ad libitum $)$ in the drinking water for $16 \mathrm{~h}$ before they were killed, as previously 
described (Neher et al. 1982). Animals were killed by decapitation and adrenal glands were excised and kept on ice.

\section{Adrenal in vivo stimulation}

Following dexamethasone treatment, animals were injected s.c. with $18 \mathrm{IU}$ ACTH per $\mathrm{kg}$ body weight and killed at the indicated times. Adrenal glands were removed, zona glomerulosa $(\mathrm{ZG})$ and $\mathrm{ZF}$ were obtained as described (Solano et al. 1988) and homogenized in $270 \mathrm{mM}$ mannitol, $10 \mathrm{mM}$ Tris $\mathrm{pH} 7 \cdot 4$ containing a cocktail of inhibitors $(100 \mathrm{mM} \mathrm{NaF}, 1 \mu \mathrm{g} / \mathrm{ml}$ pepstatin, $200 \mu \mathrm{M}$ leupeptin, $2 \mu \mathrm{g} / \mathrm{ml}$ aprotinin, $2 \mathrm{mM}$ phenylmethyl-sulfonyl fluoride (PMSF)). Cellular proteins of the homogenates were analyzed by Western blot. Steroid production was measured in the peripheral blood in order to determine the efficiency of ACTH treatment (Neher et al. 1982).

\section{Cell preparation and stimulation}

Adrenal ZF cells were obtained by trypsin digestion, following published procedures (Solano et al. 1988). ZF cells were suspended in Krebs-Ringer-Bicarbonate buffer, pH $7 \cdot 4$, containing $10 \mathrm{mM}$ glucose and $0 \cdot 5 \%$ BSA at a final concentration of $10^{5}$ cells $/ \mathrm{ml}$ and they were maintained throughout under carbogen $\left(95 \% \mathrm{O}_{2}\right.$ : $\left.5 \% \mathrm{CO}_{2}\right)$ atmosphere. Adrenal $\mathrm{ZF}$ cells were incubated with $1 \mathrm{mM} 8 \mathrm{Br}$-cAMP for 15,30 and $60 \mathrm{~min}$ at $37^{\circ} \mathrm{C}$ under carbogen atmosphere with gentle shaking. After cooling of the tubes in an ice/water bath, cells were pelleted by centrifugation at $1000 \mathrm{~g}$ for $20 \mathrm{~min}$. Incubation media were stored at $-20^{\circ} \mathrm{C}$ until corticosterone determination. Cellular pellets were suspended in $270 \mathrm{mM}$ mannitol, $10 \mathrm{mM}$ Tris $\mathrm{pH} 7 \cdot 4$, plus the cocktail of inhibitors described above and lysed in sample buffer. The samples were kept to analyze cellular proteins by Western blot.

\section{Cell cultures}

Murine Y1 adrenocortical tumor cells, generously provided by Dr Bernard Schimmer (University of Toronto, Toronto, Canada) were maintained in Ham-F10 medium, supplemented with $12.5 \%$ heatinactivated horse serum and $2.5 \%$ heat-inactivated fetal bovine serum, $1.2 \mathrm{~g} / 1 \mathrm{NaHCO}_{3}, 200 \mathrm{IU} / \mathrm{ml}$ penicillin and $200 \mathrm{mg} / \mathrm{ml}$ streptomycin sulfate (Schimmer 1981).

The MA-10 Leydig cell line is a clonal strain of mouse Leydig tumor cells, generously provided by Dr Mario Ascoli (University of Iowa, College of Medicine, Iowa City, IA, USA). These cells were maintained in Waymouth MB752/1, supplemented with 15\% horse serum, $1.2 \mathrm{~g} / \mathrm{l} \mathrm{NaHCO}_{3}, 20 \mathrm{mM}$ Hepes, $50 \mu \mathrm{g} / \mathrm{ml}$ gentamicin (Ascoli 1981).
Both cell lines were kept at $36{ }^{\circ} \mathrm{C}$ in a $5 \% \mathrm{CO}_{2}$ humidified atmosphere. After replacing the media by fresh-serum free medium, Y1 cultures were incubated with or without ACTH or 8Br-cAMP and MA-10 cells with or without $8 \mathrm{Br}$-cAMP, as stated in the legend of the corresponding figures. When indicated, AA was added together with 8Br-cAMP. In some cases, previous to the stimulations, the cells were preincubated with $10 \mu \mathrm{g} / \mathrm{ml}$ CHX (30 min) or $1 \mu \mathrm{M}$ triacsin C (240 min). Following treatments, media was kept to determine steroid production by radioimmunoassay. Y1 or MA-10 cells were washed with PBS and scraped into a buffer containing $35 \mathrm{mM}$ Tris $\mathrm{pH} \mathrm{7 \cdot 4,5} \mathrm{mM}$ EDTA, $5 \mathrm{mM}$ $\mathrm{MgCl}_{2}, 200 \mathrm{mM}$ sucrose, $0.5 \%$ Triton-X 100 and the cocktail of inhibitors described above. The suspension was incubated on ice for $10 \mathrm{~min}$, vortexed for $1 \mathrm{~min}$ and centrifuged at $11000 \mathrm{~g}$ at $4{ }^{\circ} \mathrm{C}$ for $10 \mathrm{~min}$. The supernatant (total lysate) was kept to analyze cellular proteins by Western blot.

\section{${ }^{35}$ S-Methionine incorporation and ACS4 immunoprecipitation}

Y1 cell cultures were incubated with the inclusion of $400 \mu \mathrm{Ci} / \mathrm{ml}{ }^{35} \mathrm{~S}$-methionine (specific activity $1175 \mathrm{Ci} /$ mmol; New England Nuclear, Perkin-Elmer, Boston, MA, USA) for $45 \mathrm{~min}$. Following this pre-incubation period, the cells were stimulated with $10 \mathrm{mIU} / \mathrm{ml}$ ACTH. After $30 \mathrm{~min}$ of stimulation, the cells were washed and then homogenized in a buffer consisting of $10 \mathrm{mM}$ Tris- $\mathrm{HCl} \mathrm{pH}$ 7•4, $5 \mathrm{mM}$ EDTA, $5 \mathrm{mM}$ EGTA. Proteins $(400 \mu \mathrm{g})$ of the homogenate were incubated overnight at $4{ }^{\circ} \mathrm{C}$ with $10 \mu \mathrm{l}$ of polyclonal anti-ACS4 and $30 \mu \mathrm{l}$ of protein $\mathrm{A} / \mathrm{G}$ plus-agarose in a final volume of $0.4 \mathrm{ml}$ in the following buffer $10 \mathrm{mM}$ Tris, $\mathrm{pH} 7 \cdot 4$, $130 \mathrm{mM}$ NaCl, $5 \mathrm{mM}$ EDTA, $5 \mathrm{mM}$ EGTA, 1\% Triton X-100, 0.5\% Nonidet P40, 0.5\% sodium deoxycolate, $0 \cdot 1 \% \mathrm{SDS}, 10 \mathrm{mM}$ sodium pyrophosphate, $10 \mathrm{mM} \mathrm{NaF}$ (immunoprecipitation buffer). After the incubation, the samples were centrifuged at $12000 \boldsymbol{g}$ for $4 \mathrm{~min}$. The pellets were washed four times with $0.5 \mathrm{ml}$ of immunoprecipitation buffer prior to boiling in SDS loading buffer. Samples were then analyzed by SDS-PAGE (10\% acrylamide), and dried gels exposed to autoradiography films to detect ${ }^{35} \mathrm{~S}$-methionine incorporated into newly synthesized ACS4.

\section{Western blot analysis}

Equal amounts of protein were separated by SDS-PAGE (10\% acrylamide for ACS4 and MTE-I analysis or 12\% for StAR analysis), as described by Laemmli (1970) and transferred to polyvinylidene difluoride membranes according to the procedure described by Towbin et al. (1979). ACS4, MTE-I or StAR proteins were detected using the specific antibodies and immunoreactive bands 
A

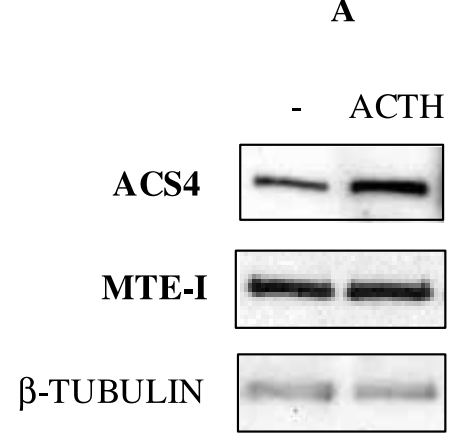

B
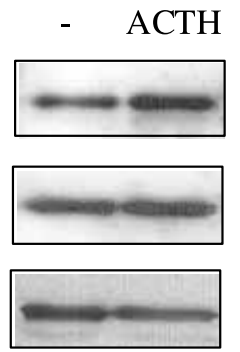

C

Time $(\min )$

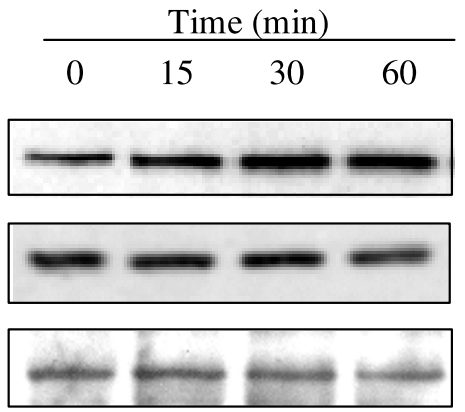

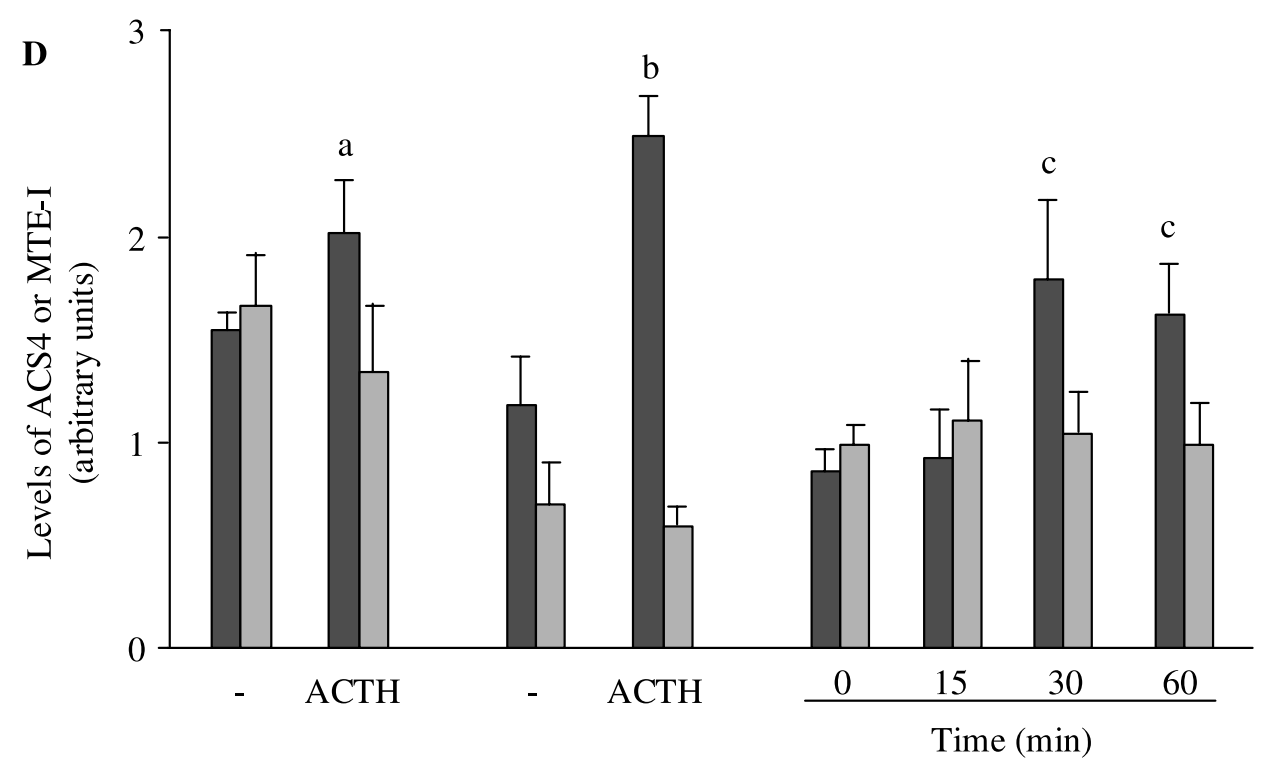

Figure 1 Effect of in vivo and in vitro stimulation of the rat adrenal gland and ZF cells on ACS4 and MTE-I protein levels. After dexamethasone treatment, animals were injected with vehicle (-) or 18 $\mathrm{IU} / \mathrm{kg}$ of adrenocorticotropin (ACTH) and killed at $30 \mathrm{~min}$. Adrenal zona glomerulosa (ZG, A) and zona fasciculata (ZF, B) were homogenized and subjected to SDS-PAGE. (C) After dexamethasone treatment, adrenal ZF cells were obtained, stimulated with $1 \mathrm{mM} 8 \mathrm{Br}$-CAMP for the indicated times, homogenized, and subjected to SDS-PAGE. Western blot analysis was performed using anti-ACS4, MTE-I and $\beta$-tubulin antibodies, sequentially. Specific bands were detected by enhanced chemiluminescence. Representative Western blots are shown in A, B and C and quantitative representation of MTE (light grey bars) or ACS4 (dark grey bars) levels relative to $\beta$-tubulin levels of three independent Western blots is shown in $D$. Results are expressed in arbitrary units as mean \pm S.D a, $P<0.05 ; b, P<0.005$ vs non-treated glands by Student's $t$-test; $c, P<0.05$ vs non-treated cells.

were visualized by enhanced chemiluminescence. In all Western blots, detection of $\beta$-tubulin was used as loading control.

\section{Northern blot analysis}

For Northern blot analysis, total RNA was isolated from Y1 and MA-10 cells by the guanidinium isothiocyanate method using TriZol reagent, according to the manufacturer protocol. Total RNA $(24 \mu \mathrm{g})$ was separated by electrophoresis on $1.5 \%$ agarose gels and blotted onto Hybond $\mathrm{N}^{+}$membranes. ACS4 mRNA was detected using a specific ${ }^{32} \mathrm{P}$-labeled cDNA probe (Kang et al. 1997). The levels of 28S RNA were also detected and used as loading control.

\section{siRNA transfection}

siRNAs targeting ACS4 and MTE-I coding sequences were custom-designed by Dharmacon (Lafayette, $\mathrm{CO}, \mathrm{USA})$. One day before transfection, $\mathrm{Y} 1$ cells $\left(5 \times 10^{5}\right.$ cells/well $)$ were grown up to $80 \%$ confluence onto 24-well plates. Transfection was performed using siRNA (350 nM) with Opti-MEM medium and $2 \mu \mathrm{l}$ Lipofectamine 2000 reagent according to the instructions of the manufacturer. Cells were placed into normal 


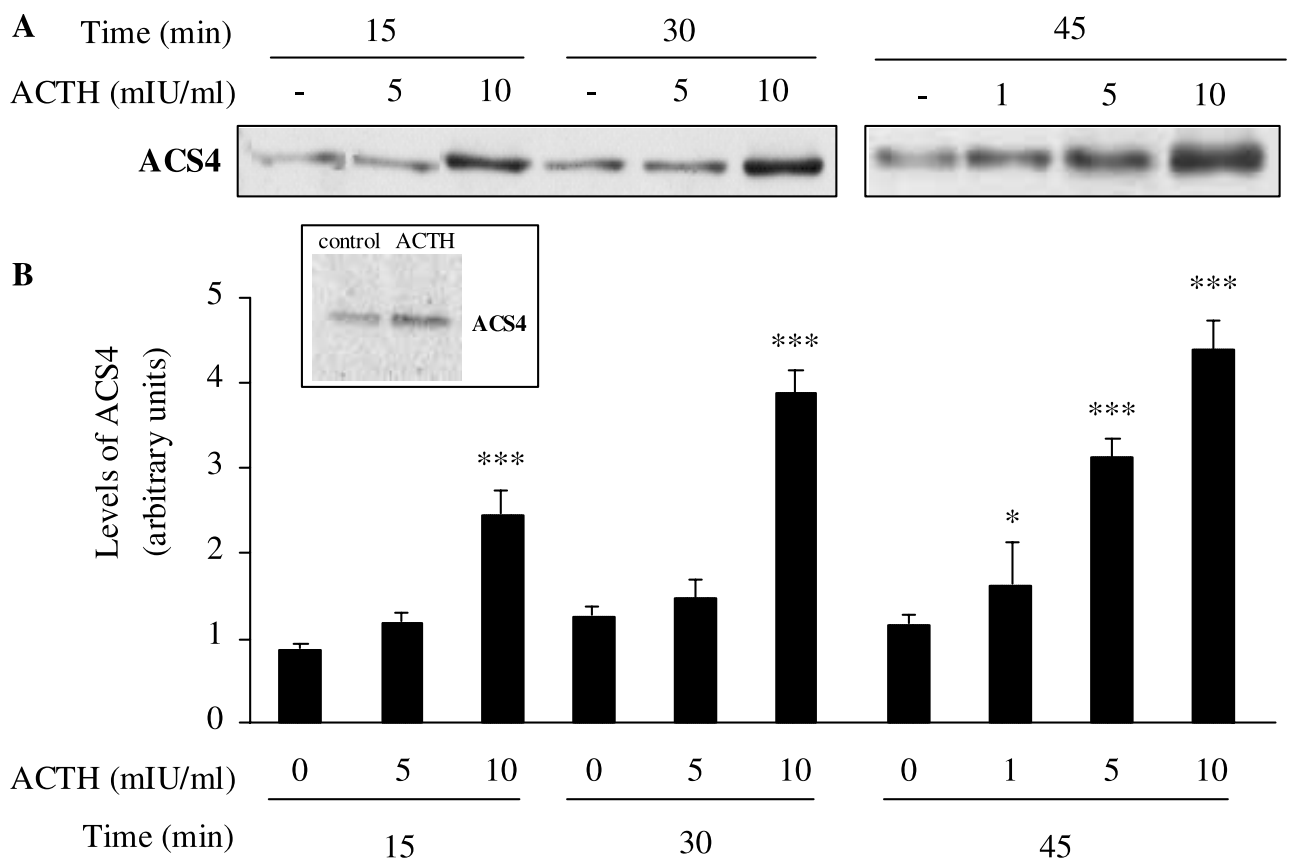

Figure 2 Effect of ACTH stimulation of $Y 1$ cells on ACS4 and MTE-I levels. Adrenocortical Y1 cells were stimulated with ACTH (doses and times stated in the figure). Cellular proteins were subjected to SDS-PAGE and Western blot analysis was performed using anti-ACS4 antibodies. Specific bands were detected by enhanced chemiluminescence. (A) Western blot representative of three independent experiments. (B) Quantitative representation of three independent Western blots. Intensity of the specific bands was quantified and results are expressed in arbitrary units as mean \pm S.D. ${ }^{\star} P<0 \cdot 1$ and ${ }^{\star * \star} P<0.001$ vs non treated cells. Inset, representative autoradiography of ${ }^{35}$ S-Methionine incorporated into ACS4 by Y1 cells. After ${ }^{35}$ S-Methionine incorporation and ACTH stimulation, ACS4 protein was immunoprecipitated using a specific antibody and the presence of ${ }^{35}$ S-Methionine-labeled ACS4 was analyzed by SDS-PAGE and autoradiography, as described in Materials and methods.

culture medium for $6 \mathrm{~h}$ after transfection and further grown for $48 \mathrm{~h}$. Y1 cells were stimulated with $5 \mathrm{mIU} / \mathrm{ml}$ ACTH in culture medium containing $0 \cdot 1 \%$ fatty acid-free BSA, in the presence or absence of $0.3 \mathrm{mM}$ AA. Following treatments, media was kept to determine steroid production by radioimmunoassay.

\section{Protein determination}

Protein concentrations were determined by Bradford assay, using BSA as standard (Bradford 1976).

\section{Statistics}

Results are shown as the mean \pm S.D Unless otherwise indicated, statistical significance was evaluated using ANOVA followed by Tukey test. $P<0 \cdot 05$ was considered significant.

\section{Results}

Given that ACTH regulates intracellular concentration of AA in adrenal cells and that ACS4 and MTE-I are enzymes involved in AA release, the first experiments were performed in order to determine whether ACTH has any effect on ACS4 and MTE-I protein levels. With this purpose, we analyzed the levels of both proteins in adrenal glands from animals stimulated with a single dose of ACTH for $30 \mathrm{~min}$. As shown in Fig. 1, Western blot analysis revealed an increase in ACS4 protein levels in both ZG (Fig. 1, panels A and D) and ZF (Fig. 1, panels $\mathrm{B}$ and $\mathrm{D})$. In addition, when isolated rat adrenal $\mathrm{ZF}$ cells were stimulated in vitro with $8 \mathrm{Br}$-cAMP (15-60 min), we also observed an increase in the protein (Fig. 1, panels $\mathrm{C}$ and $\mathrm{D}$ ). In contrast, neither in vivo ACTH treatment nor in vitro $8 \mathrm{Br}$-cAMP incubation modifies the levels of MTE-I (Fig. 1).

In order to further characterize the effect of hormone action on ACS4 levels, we used two well recognized steroidogenic cell lines, adrenocortical Y1 and Leydig MA10 cells. The levels of ACS4 and MTE-I were analyzed in $\mathrm{Y} 1$ cells stimulated with different concentrations of ACTH for different periods of time. None of the concentrations or times tested $(1-10 \mathrm{mIU} / \mathrm{ml}$, $15-45 \mathrm{~min}$ ) proved to modify the intracellular content of MTE-I (data not shown). However, ACTH produces an 

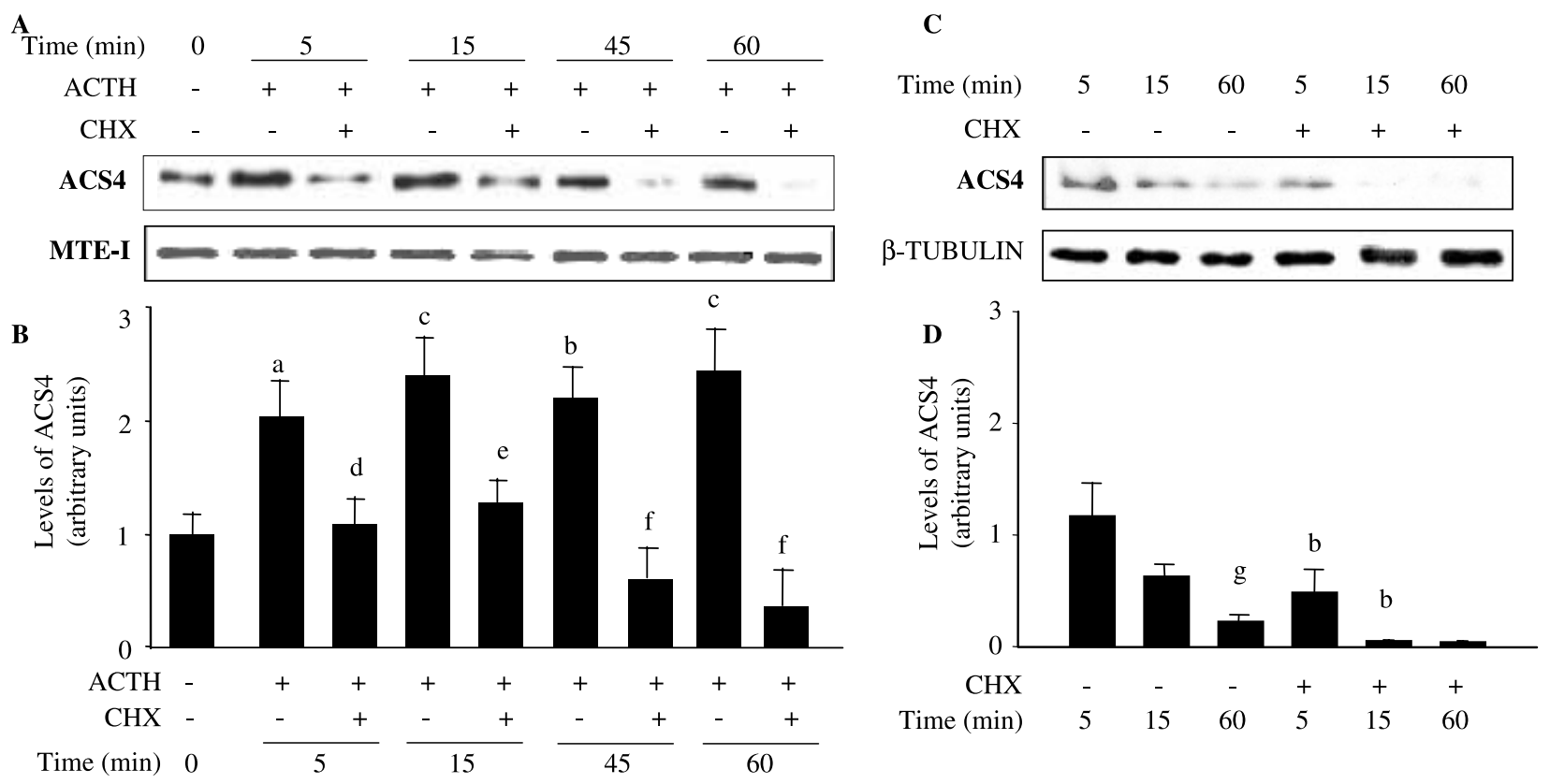

Figure 3 Effect of $\mathrm{CHX}$ on ACS4 protein levels in $\mathrm{Y} 1$ cells. Adrenocortical $\mathrm{Y} 1$ cells were preincubated with or without $10 \mu \mathrm{g} / \mathrm{ml}$ $\mathrm{CHX}$ during $30 \mathrm{~min}$ and further treated with $10 \mathrm{mIU} / \mathrm{ml} \mathrm{ACTH} \mathrm{(A} \mathrm{and} \mathrm{B)} \mathrm{during} \mathrm{the} \mathrm{indicated} \mathrm{times} \mathrm{or} \mathrm{its} \mathrm{vehicle} \mathrm{(C} \mathrm{and} \mathrm{D).} \mathrm{Cellular}$ proteins were subjected to SDS-PAGE and Western blot analysis using an anti-ACS4 antibody (A and C). After stripping, the membranes were reprobed using an antibody against MTE-I (A) or $\beta$-tubulin (C). Specific bands were detected by enhanced chemiluminescence. ( $A$ and $C$ ) Western blot representative of three independent experiments. (B and D) Densitometry quantitation of three independent Western blots. Intensity of ACS4 specific bands was quantified and results are expressed in arbitrary units as mean \pm S.D a, $P<0.05 ; \mathrm{b}, P<0.01 ; \mathrm{c}, P<0.001$ vs non-treated cells; $\mathrm{d}, P<0.05 ; \mathrm{e}, P<0.01 ; \mathrm{f}, P<0.001$ vs ACTH alone; $\mathrm{g}, P<0.01$ vs time 0 .

increase of ACS4 levels evaluated by Western blot. Analysis of the intensity of ACS4 signal demonstrated that ACTH $(10 \mathrm{mIU} / \mathrm{ml})$ induces ACS4 levels to rise after $15 \mathrm{~min}$ (Fig. 2) and $5 \mathrm{mIU} / \mathrm{ml}$ of ACTH is able to induce ACS4 protein after 45 min (Fig. 2). Maximal induction by ACTH (approximately 3-fold) was reached using $10 \mathrm{mIU} / \mathrm{ml}$ during $30 \mathrm{~min}$ and remained constant thereafter. The observed effect of the hormone on ACS4 protein levels could be due to an action on the rate of synthesis of the protein or on the rate of its degradation. Then, the effect of ACTH on ACS4 induction was also evaluated by ${ }^{35} \mathrm{~S}-\mathrm{Met}$ incorporation and immunoprecipitation. As shown in the inset of Fig. 2, ACTH increases the incorporation of the radioactive amino acid into ACS4. To confirm this result, we next studied the effect of CHX on ACS4 levels. For this purpose, Y1 adrenal cells were incubated with or without $10 \mu \mathrm{g} / \mathrm{ml}$ of CHX during $30 \mathrm{~min}$ before ACTH stimulus (5-60 min). Fig. 3, panel A shows that ACTH induces ACS4 levels as early as $5 \mathrm{~min}$, while there is no effect on MTE-I protein levels. CHX treatment reduces ACTH-induced ACS4 protein levels at all times studied (Fig. 3, panels A and B). Notwithstanding a possible effect of the hormone on protein degradation, these results indicate that $\mathrm{ACTH}$ affects, at least in part, ACS4 synthesis. Basal ACS4 levels decreased rapidly after serum deprivation and this decrease is more evident after CHX treatment (Fig. 3, panels C and D).

The next series of experiments was carried out in order to analyze whether the hormonal regulation of ACS4 protein levels is also observed with $8 \mathrm{Br}$-cAMP in $\mathrm{Y} 1$ and in MA-10 Leydig cells, since in MA-10 cells the participation of AA as modulator of the hormone- and cAMP-induced StAR protein levels and steroidogenesis is well recognized (Wang et al. 2000). The results shown in Fig. 4 indicate that hormone-mediated induction of ACS4 is a cAMP-dependent process, since in both cell lines the effect is reproduced by $8 \mathrm{Br}$-cAMP, a permeable analog of the second messenger cAMP. As expected, StAR protein is induced by $8 \mathrm{Br}$-cAMP treatment (Fig. 4, panel A), while there is no action of the second messenger on MTE-I levels (Fig. 4, panel C).

In order to investigate whether the acute effect of hormone on ACS4 protein levels is due to an increase in protein or in RNA synthesis, we studied the effect of hormone treatment on ACS4 RNA abundance in Y1 (Fig. 5, panel A) and MA-10 cells (Fig. 5, panel B). In contrast with the effect observed on protein levels, stimulation of both cell lines did not change ACS4 RNA levels during the first hour of treatment. The effect on mRNA levels could only be observed after 1.5 and $6 \mathrm{~h}$ of 
A
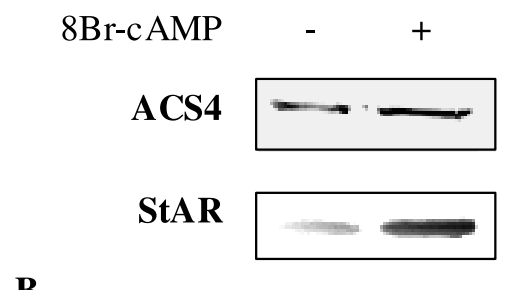

B

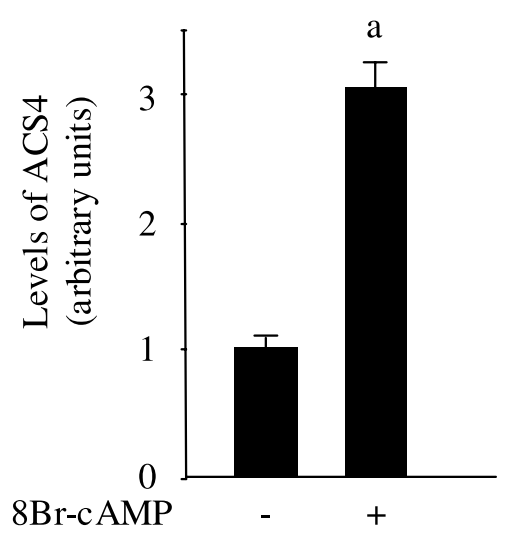

C

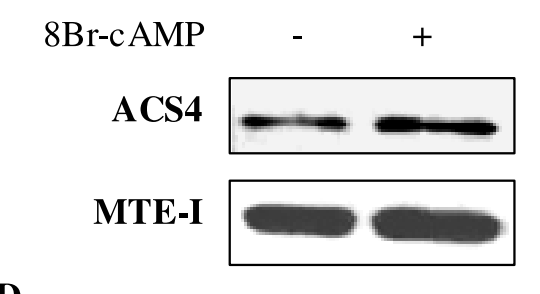

D

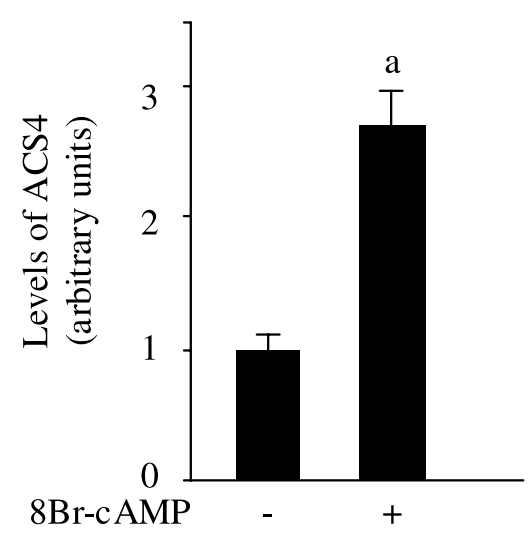

Figure 4 Effect of 8Br-cAMP on ACS4 protein levels. Y1 cells (A and B) and MA-10 cells (C and D) stimulated with $1 \mathrm{mM} 8 \mathrm{Br}$-cAMP during $60 \mathrm{~min}$. Cellular proteins were subjected to SDS-PAGE and Western blot analysis using an anti-ACS4 antibody. After stripping, the membranes were reprobed using an antibody against StAR (A) or MTE-I (C). Specific bands were detected by enhanced chemiluminescence. ( $A$ and $C$ ) Representative Western blot of three independent experiments. (B and D) Densitometry quantitation of three independent Western blots. Intensity of ACS4 specific bands was quantified and results are expressed in arbitrary units as mean \pm S.D. a, $P<0.001$ vs non-treated cells by Student's $t$-test.

treatment in Y1 and MA-10 cells respectively, indicating that short term effect of hormone treatment on protein levels is due to an increase in mRNA translation and not in mRNA synthesis.

Previously, we have demonstrated the role of ACS4 in steroidogenesis showing that inhibition of ACS4 activity using triacsin $\mathrm{C}$ results in an inhibition of steroidogenesis. Triacsin $\mathrm{C}$ acts as an inhibitor of Acyl-CoA synthetases, with a preferential effect on arachidonoylCoA synthetases in intact cells (Tomoda et al. 1987, Hartman et al. 1989). We also showed that the hormonal regulation of steroid synthesis needs the concerted action of ACS4 and MTE-I (Maloberti et al. 2002). In addition, it is also known that AA regulates StAR induction and steroidogenesis (Wang et al. 2000). Thus, in order to confirm that the inhibition of ACS4 activity leads to a reduction of the substrate of MTE-I and therefore to the inhibition of AA release, StAR induction and steroidogenesis, we next studied the ability of exogenous AA to overcome the inhibition exerted by triacsin $\mathrm{C}$. For that purpose, MA10 cells were stimulated with 8Br-cAMP in the presence and absence of triacsin $\mathrm{C}$ and AA. As shown in Fig. 6A, triacsin $\mathrm{C}$ decreases progesterone production stimulated by $8 \mathrm{Br}-\mathrm{cAMP}$. The addition of AA into the culture medium reverses the inhibitory effect of triacsin C (Fig. 6, panel A). Moreover, triacsin C reduces $\mathrm{StAR}$ protein induction by $8 \mathrm{Br}-\mathrm{cAMP}$, an effect that is also overcome by the addition of AA (Fig. 6, panel B). As expected triacsin $\mathrm{C}$ treatment does not affect ACS4 protein levels (Fig. 6, panel B). Even when ACS4 is present, its action is inhibited by this compound. Then, StAR protein is not induced and steroidogenesis is reduced. Regarding the effect of AA on CHX action, exogenous AA was not capable of rescuing steroid biosynthesis inhibited by CHX (8Br-cAMP, 8.5 $\pm 0 \cdot 8$; $8 \mathrm{Br}-\mathrm{cAMP}+\mathrm{CHX}, \quad 0 \cdot 6 \pm 0 \cdot 1 ; \quad 8 \mathrm{Br}-\mathrm{cAMP}+\mathrm{CHX}+\mathrm{AA}$, $1 \cdot 3 \pm 0 \cdot 2 \mathrm{ng}$ progesterone $/ \mathrm{ml})$, expectable result given that protein synthesis is needed for StAR protein induction. Similar results were obtained when Y1 adrenocortical cells were used as a steroidogenic system (data not shown).

In order to confirm the obligatory role of ACS4 on steroidogenesis, we knocked out its expression in Y1 cells by using a siRNA approach. Transfection with siRNA against ACS4 produced a marked reduction of acyl-CoA synthetase levels as assayed by Western blot (Fig. 7, panel A). The reduction of ACS4 levels by siRNA transfection concomitantly reduced the levels of ACTH-induced StAR protein levels (Fig. 7, panel A). These results are similar to those obtained by the 
A

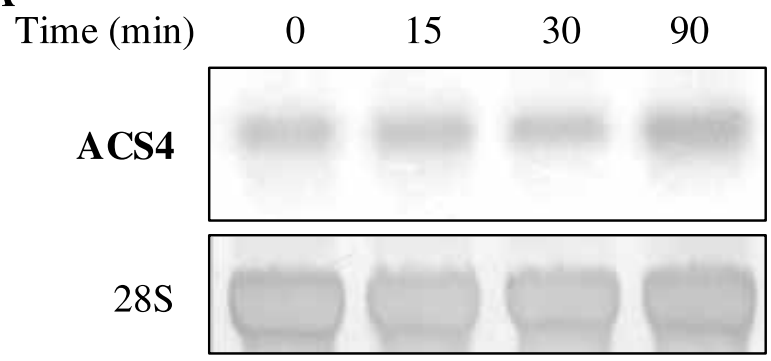

B

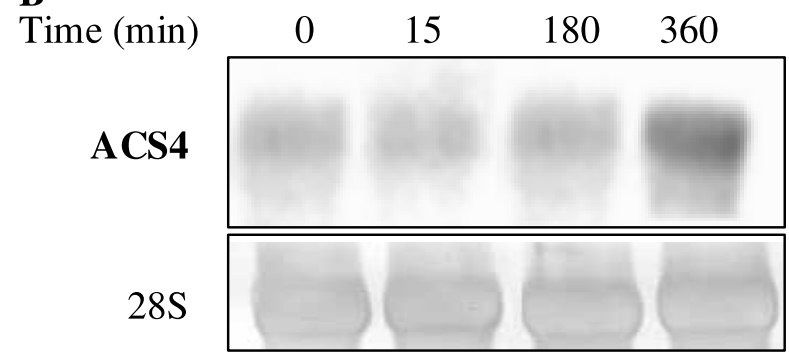

Figure 5 Analysis of ACS4 mRNA levels in $\mathrm{Y} 1$ and MA-10 cells. Y1 (A) and MA-10 (B) cells were incubated with $1 \mathrm{mM}$ $8 \mathrm{Br}$-cAMP during the indicated times. Total RNA was extracted following standard procedures described in Materials and methods, and analyzed by Northern blot with a specific probe to ACS4 mRNA. The figure shows representative Northern blots of ACS4 mRNA.

inhibition of ACS4 activity by triacsin C (Fig. 6). Also, progesterone production by $\mathrm{Y} 1$ cells transfected with siRNA against ACS4 was inhibited when compared with control cells (Fig. 7, panel B). Based on the fact that ACS4 and MTE-I act together on AA release, silencing the expression of MTE-I should also result in inhibition of hormone-induced steroid synthesis. siRNA duplexes directed against MTE-I were also produced for transfection of $\mathrm{Y} 1$ cells. siRNA transfection resulted in a marked reduction of MTE-I and StAR protein levels and steroidogenesis as detected by Western blot and RIA respectively (Fig. 7, panels A and B). The concerted action of ACS4 and MTE-I on AA release is firmly supported by the experiments showing that addition of exogenous AA blunted the inhibition of progesterone production produced by both siRNAs (Fig. 7, panel B). As expected, since AA facilitates cholesterol accessibility to the inner mitochondrial membrane, steroid synthesis was not affected by ACS4 or MTE-I siRNA transfection when stimulated by 22(R)-OH-cholesterol, a permeable analog of cholesterol (Fig. 7, panel B inset).

\section{Discussion}

The inhibitory effect of cycloheximide on the activation of steroidogenesis has been known for many years

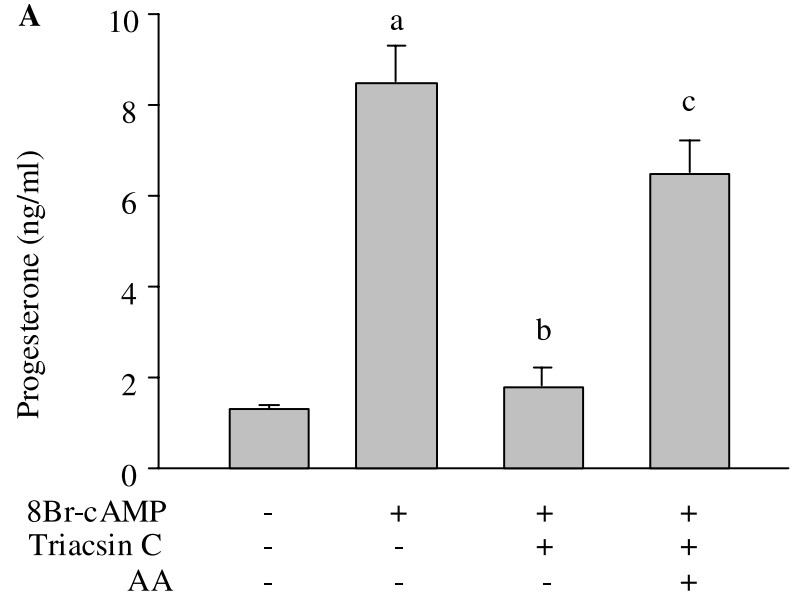

B

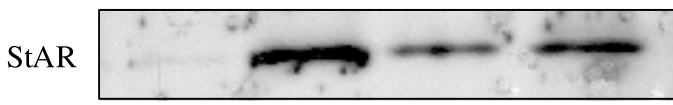

ACS4

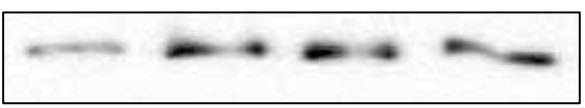

\section{$\beta$-TUBULIN}

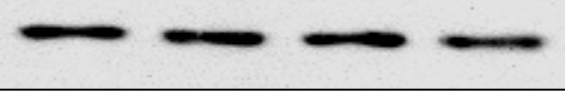

Figure 6 Effect of AA on cAMP-stimulated steroid production and StAR protein levels inhibited by triacsin C (ACS4 inhibitor). MA-10 Leydig cells were incubated with $1 \mathrm{mM}$ triacsin $\mathrm{C}$ during $240 \mathrm{~min}$, previous to the stimulation with $1 \mathrm{mM} 8 \mathrm{Br}$-cAMP in the presence or absence of $0.3 \mathrm{mM} \mathrm{AA}$. (A) Steroid production was evaluated determining progesterone concentrations in the culture media after 60 min of treatment. Results are expressed as $\mathrm{ng}$ progesterone $/ \mathrm{ml}$ and values represent the mean \pm S.D. of three independent experiments. a, $P<0.001$ vs non treated cells; b, $P<0.001$ vs $8 \mathrm{Br}$-cAMP alone, c, $P<0.001$ vs 8Br-cAMP+triacsin C alone. (B) Representative Western blot of StAR and ACS4 proteins in the cell lysates.

(Garren et al. 1965, Cooke et al. 1975) and the kinetics of the inhibition has led to the hypothesis that a labile protein is required for hormone action (Garren et al. 1965, 1971).

The rate limiting step in steroidogenesis is the delivery of the substrate cholesterol to the inner mitochondrial membrane where P450 scc is located. A fundamental observation was that this regulation had an absolute requirement for protein synthesis. The role of the newly synthesized protein(s) would be to mediate the transfer of cholesterol from the outer mitochondrial membrane through the aqueous intermediate space.

Recently, we published results supporting the regulation of AA release and hormone-induced steroid synthesis by the concerted action of ACS4 and MTE-I (Maloberti et al. 2002). In the present report we describe the hormonal regulation of ACS4 protein levels. Interestingly, the activity of this protein appears to be 
A

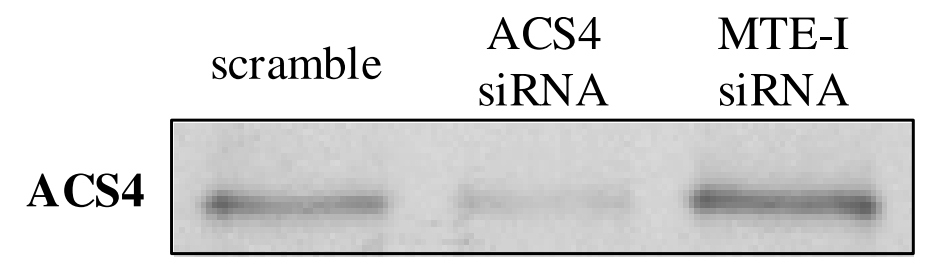

MTE-I

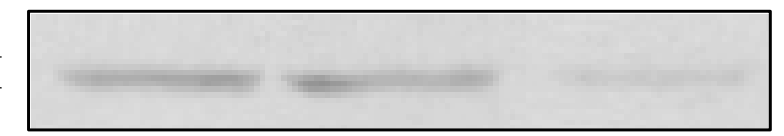

StAR

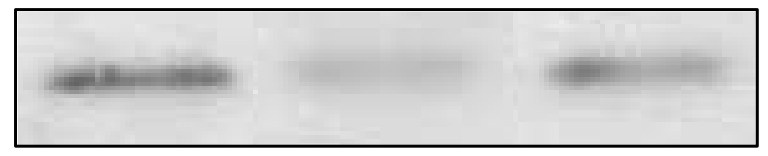

$\beta$-TUBULIN

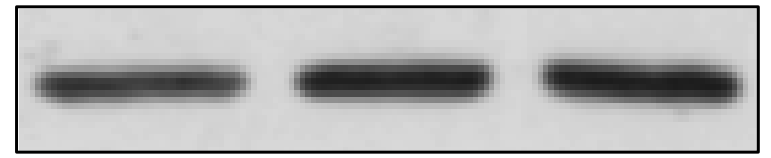

B

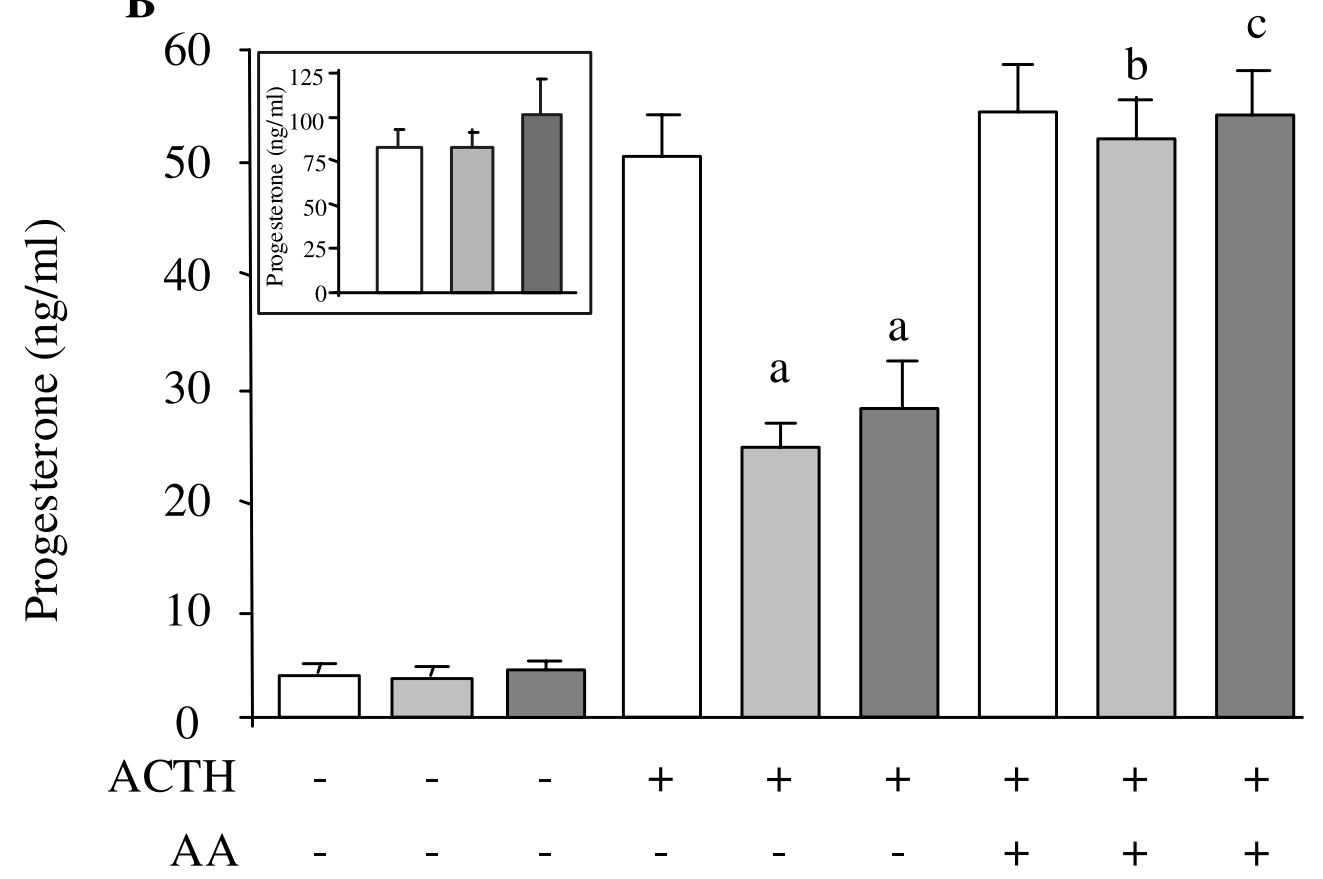

Figure 7 Effect of ACS4 and MTE-I siRNA on protein levels and steroid production. Y1 cells were transfected with siRNA targeted against ACS4, MTE-I or a scramble siRNA, as described in Materials and methods. (A) Representative Western blot of three independent experiments. Cellular proteins were subjected to SDS-PAGE and Western blot analysis using anti-ACS4, MTE-I, StAR and $\beta$-tubulin antibodies sequentially. Specific bands were detected by enhanced chemiluminescence. (B) Progesterone production after 60 min of treatment. Y1 cells transfected with scramble (open bars), ACS4 (light grey bars) or MTE-I (dark grey bars) siRNA were incubated in the presence or absence of $5 \mathrm{mIU} / \mathrm{ml} \mathrm{ACTH}$ and with or without $0.3 \mathrm{mM} \mathrm{AA}$. Inset: Progesterone production by $\mathrm{Y} 1$ cells incubated for $60 \mathrm{~min}$ in the presence of $5 \mu \mathrm{M} \mathrm{22R}(\mathrm{OH})$-cholesterol. Results are expressed as the mean \pm S.D. of one representative experiment performed in triplicate. a: $P<0.01 \mathrm{vs}$. scramble siRNA-transfected+ACTH; b: $P<0.05$ vs. ACS4 siRNA-transfected+ACTH; c: $P<0.01$ vs. MTE-I siRNA-transfected+ACTH. 
essential for StAR induction. The present data led us to propose that hormone stimulation of AA release, StAR induction and steroid production through the cAMPdependent phosphorylation involves the new synthesis of ACS4 as an early step.

The data supporting this hypothesis are: i) the inhibition of protein synthesis decreases basal levels of ACS4 rapidly, ii) ACS4 is rapidly induced by hormones through a cAMP-dependent process in vivo and in vitro (ZF and ZG of adrenal tissue, ZF cells, Y1 adrenal cells and MA10 Leydig cells), iii) the acute increase in protein levels seems to be due to an increase in protein synthesis rather than to a decrease in protein degradation or an increase in mRNA levels, iv) exogenous AA is capable of restoring StAR induction and steroidogenic activity of cells treated with the ACS4 activity inhibitor triacsin C, v) ACS4-targeted siRNA reduces both ACS4 and StAR protein levels, and vi) ACS4-targeted siRNA results also in a decreased steroid production, an effect that is reversed by exogenous arachidonic acid.

According to this model, ACS4 induction should be an early event in hormone action. Here we demonstrate a rapid action ( $5 \mathrm{~min}$ ) of hormone treatment on ACS4 induction. This protein is newly synthesized since 30 min of incubation with the protein-synthesis inhibitor prior to hormone treatment is sufficient to abolish the induction of ACS4. These results are confirmed by the ${ }^{35} \mathrm{~S}$-methionine incorporation experiments. Moreover, in the presence of CHX, both basal and stimulated protein levels decrease rapidly, suggesting that ACS4 is a high turnover protein. The acute effect of the hormone is at the level of protein synthesis, since mRNA levels can be stimulated only after a longer time of stimulation.

The results in the present report suggest a hormone regulation of arachidonoyl-CoA (AA-CoA) levels through the control of ACS4 induction. ACS4 characteristically being a protein with a high turnover is in agreement with the fact that fatty acyl-CoA esters need a tight control of their intracellular concentrations since they are important intermediates in lipid metabolism and signal molecules, being strong detergents at the same time.

On the other hand, the induction of the acyl-CoA thioesterase MTE-I appears not to be controlled by hormone treatment. Previous observations showed that ACTH stimulates MTE-I activity in Y1 cells (Maloberti et al. 2002). The thioesterase activity can be regulated by PKA-dependent phosphorylation (Maloberti et al. 2000), however, it also requires an acyl-CoA pool as a source of AA. Therefore we cannot rule out a possible activation of the enzyme by a hormone-increased availability of its substrate, concept supported by the fact that ACS4 is regulated by hormone treatment. The obligatory role of MTE-I could be demonstrated by the use of siRNA, showing that reduction of the expression of MTE-I is accompanied by reduction in steroid synthesis, an effect that can be reversed by addition of AA.

The role of ACS4 in steroidogenesis was previously demonstrated by the fact that an inhibitor of the enzyme activity reduces steroid production. This is further supported by the results obtained in knock out experiments using siRNA showing that a reduction in the levels of ACS4 reduces steroid synthesis. Moreover, here we also demonstrate that $\mathrm{AA}$ can restore steroidogenesis when the activity of ACS4 is inhibited by triacsin $\mathrm{C}$ or when ACS4 expression is inhibited by siRNA. The results of the present study indicate that ACS4 induction and AA release are essential for steroid production and StAR protein expression. Since StAR protein was demonstrated to play a critical role in the cholesterol transfer to the mitochondrial inner membrane, our results are in agreement with earlier experiments suggesting that AA regulates steroidogenesis at the rate-limiting step of mitochondrial cholesterol transfer (Wang et al. 2000).

It has been suggested that the intracellular concentration of unbound acyl-CoA esters is tightly controlled by the presence of specific acyl-CoA binding proteins (ACBP) and acyl-CoA thioesterases (Faergeman \& Knudsen 1997, Knudsen et al. 2000). In such a cellular environment, transport by diffusion of unbound acyl-CoA esters is very unlikely, suggesting that supply of substrate to acyl-CoA-consuming enzymes depends on direct transfer from acyl-CoA synthetases, or relies on ACBPs or carrier proteins. In this regard, it is known that an acyl-CoA binding protein known also as DBI (diazepam binding inhibitor) is expressed in high concentration in specialized cells such as steroid producing cells of the adrenal cortex and testis (Papadopoulos 1993). Thus it is possible that after the hormone induction of the acyl-CoA synthetase, the AA-CoA binds to DBI, which in turn binds to the peripheral benzodiazepine receptor (PBR) located in the outer mitochondrial membrane (Papadopoulous 1993). This will possibly lead to a facilitated transfer of AA-CoA to the mitochondria, with the consequent availability of the substrate for the thioesterase at its site of action. Although the role of AA in StAR induction and steroidogenesis is well recognized, we cannot rule out a direct effect of AA on cholesterol transfer. Cholesterol binding to P450 scc in lipid vesicles is greatly potentiated when the local membrane is rendered more fluid by the addition of free fatty acids (Dhariwal \& Jefcoate 1989). The increase in membrane fluidity in the presence of fatty acids possibly favors the interaction of cholesterol with PBR, StAR or P450 scc (Dhariwal \& Jefcoate 1989, Petrescu et al. 2001, Jefcoate 2002). Further studies need to be performed to elucidate this process.

Taken together our current data indicate the presence of a new hormone-dependent labile protein in steroidogenic tissues (ACS4) essential for AA release, 
StAR induction and steroidogenesis. This study further supports the new concept in the regulation of intracellular distribution of AA through a mechanism different from the classical phospholipase $\mathrm{A}_{2}$-mediated pathway that involves the activity of a hormone-induced acyl-CoA synthetase and a hormone-regulated acyl-CoA thioesterase.

\section{Acknowledgements}

This work was supported by grants from University of Buenos Aires (UBA) to EJP (M064), GP (M059) and FGM (M079) and Agencia Nacional de Promoción Científica y Tecnológica (ANPGYT) to EJP (PICT 6738). Thanks are also due to Carlos F Méndez for critical reading. The authors declare that there is no conflict of interest that would prejudice the impartiality of this scientific work.

\section{References}

Ascoli M 1981 Characterization of several clonal lines of cultured Leydig tumor cells gonadotropin receptors and steroidogenic responses. Endocrinology 108 88-95.

Bradford MM 1976 A rapid and sensitive method for quantitation of microgram quantities of protein utilizing the principle of protein-dye binding. Analytical Biochemistry 72 248-254.

Clark BJ, Wells J, King SR \& Stocco D 1994 The purification, cloning, and expression of a novel luteinizing hormone-induced mitochondrial protein in MA-10 mouse Leydig tumor cells. Characterization of the steroidogenic acute regulatory protein (StAR). Fournal of Biological Chemistry $26928314-28322$.

Cooke BA, Janszen FH, Clotscher WF \& van der Molen HJ 1975 Effect of protein-synthesis inhibitors on testosterone production in rat testis interstitial tissue and Leydig-cell preparations. Biochemical fournal 150 413-418.

Cooke BA, Dirami G, Chaudry L, Choi MSK, Abayasekara DRE \& Phipp L 1991 Release of arachidonic acid and the effects of corticosteroids on steroidogenesis in rat testis Leydig cells. Fournal of Steroid Biochemistry and Molecular Biology 40 465-471.

Crivello JF \& Jefcoate GR 1980 Intracellular movement of cholesterol in rat adrenal cells. Kinetic and effect of inhibitors. Fournal of Biological Chemistry 255 8144-8151.

Dada L, Cornejo Maciel F, Neuman I, Mele PG, Maloberti P, Paz C, Cymeryng C, Finkielstein C, Mendez CF \& Podestá EJ 1996 Cytosolic and mitochondrial proteins as possible targets of cycloheximide effect on adrenal steroidogenesis. Endocrine Research 22 533-539.

Dhariwal MS \& Jefcoate CR 1989 Cholesterol metabolism by purified cytochrome P-450 scc is highly stimulated by octyl glucoside and stearic acid exclusively in large unilamellar phospholipid vesicles. Biochemistry 28 8397-8402.

Didolkar A \& Sundaram K 1987 Arachidonic acid is involved in the regulation of hCG induced steroidogenesis in rat Leydig cells. Life Sciences 41 471-477.

Dix CJ, Habberfield AD, Sullivan MH \& Cooke BA 1984 Inhibition of steroid production in Leydig cells by non-steroidal anti-inflammatory and related compounds evidence for the involvement of lipoxygenase products in steroidogenesis. Biochemical fournal 219 529-537.

Dufau ML, Tsuruhara T, Horner K, Podestá E \& Catt K 1977 Intermediate role of adenosine $3^{\prime} 5^{\prime}$-cyclic monophosphate and protein kinase during gonadotropin-induced steroidogenesis in testicular interstitial cells. PNAS 4 3419-3423.
Faergeman NJ \& Knudsen J 1997 Role of long-chain fatty acyl-CoA esters in the regulation of metabolism and in cell signaling. Biochemical fournal 323 1-12.

Finkielstein C, Cymeryng C, Paz C, Neuman I, Dada L, Cornejo Maciel F, Mele PG, Mendez CF Maloberti P, Solano A, Schimmer BP \& Podestá EJ 1996 Characterization of the cDNA corresponding to a phosphoprotein (p43) intermediary in the action of ACTH. Endocrine Research 22 521-532.

Finkielstein C, Maloberti P, Mendez CF, Paz C, Cornejo Maciel F, Cymeryng C, Neuman I, Dada L, Mele PG, Solano A \& Podestá EJ 1998 An adrenocorticotropin regulated phosphoprotein intermediary in steroid synthesis is similar to an acyl-CoA thioesterase enzyme. European Fournal of Biochemistry 256 60-66.

Garren LD, Ney RL \& Davis WW 1965 Studies on the role of protein synthesis in the regulation of corticosterone production by adrenocorticotropic hormone in vivo. PNAS 53 1443-1450.

Garren LD, Gill GN, Masui H \& Walton GM 1971 On the mechanism of action of ACTH. Recent Progress in Hormone Research 27 433-478.

Hartman EJ, Omura S \& Laposata M 1989 Triacsin C a diferential inhibitor of arachidonoyl-CoA synthetase and nonspecific long chain acyl-CoA synthetase. Prostaglandins 37 655-671.

Jefcoate C 2002 High-flux mitochondrial cholesterol trafficking, a specialized function of the adrenal cortex. Fournal of Clinical Investigation 110 881-890.

Kang M, Fujino T, Sasano H, Minekura H, Yabuki N, Nagura H, Iijima H \& Yamamoto T 1997 A novel arachidonate-preferring acyl-CoA synthetase is present in steroidogenic cells of the rat adrenal, ovary, and testis. PNAS 94 2880-2884.

Knudsen J, Neergaard TBF, Gaigg B, Jensen MV \& Hansen JK 2000 Role of acyl-CoA binding protein in acyl-CoA metabolism and acyl-CoA mediated cell signaling. Symposium The role of long chain fatty acyl-CoAs as signaling molecules in cellular metabolism. American Society for Nutritional Sciences. Fournal of Nutrition $130294 \mathrm{~S}-298 \mathrm{~S}$

Laemmli UK 1970 Cleavage of structural proteins during the assembly of the head of bacteriophage T4. Nature 227 680-685.

Maloberti P, Lozano RC, Mele PG, Cano F, Colonna C, Mendez CF, Paz C \& Podestá EJ 2002 Concerted regulation of free arachidonic acid and hormone-induced steroid synthesis by acyl-CoA thioesterase and Acyl-CoA synthetases in adrenal cells. European Fournal of Biochemistry $2695599-5607$.

Maloberti P, Mele PG, Neuman I, Cornejo Maciel F, Cano F, Bey P, Paz C \& Podestá EJ 2000 Regulation of arachidonic acid release in steroidogenesis role of a new acyl-CoA thioesterase (ARTISt). Endocrine Research 26 653-662.

Mele PF, Dada LA, Paz C, Neuman I, Cymeryng CB, Mendez CF, Finkielstein CV, Cornejo Maciel F \& Podestá EJ 1997 Involvement of arachidonic acid and the lipoxygenase pathway in mediating luteinizing hormone-induced testosterone synthesis in rat Leydig cells. Endocrine Research 23 15-26.

Moraga PF, Llanos MN \& Ronco AM 1997 Arachidonic acid release from rat Leydig cells depends on the presence of luteinizing hormone/human chorionic gonadotropin receptors. Fournal of Endocrinology 154 201-209.

Neher R, Milani A, Solano AR \& Podestá EJ 1982 Compartmentalization of corticotropin-dependent steroidogenic factors in adrenal cortex evidence for a post-translational cascade in stimulation of cholesterol side chain split. PNAS $\mathbf{7 9}$ $1727-1731$.

Papadopoulos V 1993 Peripheral-type benzodiazepine/diazepam binding inhibitor receptor biological role in steroidogenic cell function. Endocrine Reviews 14 222-240.

Paz C, Dada LA, Cornejo Maciel F, Mele PG, Cymeryng CB, Neuman I, Mendez CF, Finkielstein CV, Solano AR \& Podestá EJ 1994 Purification of a novel 43-kDa protein (p43) intermediary in the activation of steroidogenesis from rat adrenal gland. European Fournal of Biochemistry 224 709-716. 
Petrescu AD, Gallegos AM, Okamura Y, Strauss JF III \& Schroeder F 2001 Steroidogenic acute regulatory protein binds cholesterol and modulates mitochondrial membrane sterol domain dynamics. Journal of Biological Chemistry 276 36970-36982.

Privalle CT, Crivello JF \& Jefcoate CR 1983 Regulation of intramitochondrial cholesterol transfer to side-chain cleavage cytochrome P-450 scc in rat adrenal gland. PNAS $80702-706$.

Reinhart AJ, Williams SC \& Stocco DM 1999 Transcriptional regulation of the StAR gene. Molecular and Cellular Endocrinology 151 161-169.

Sala G, Hayoshi K, Catt K \& Dufau M 1979 The intermediate role of cyclic AMP in stimulation of corticosterone synthesis. Fournal of Biological Chemistry 254 3861-3865.

Schimmer BP 1981 The adrenocortical tumor cell line Y1. In Functionally differentiated cell lines, pp 61-92. Ed. G Sato. New York: Alan R. Liss Inc.

Solano AR, Dada L \& Podestá EJ 1988 Lipoxygenase products as common intermediates in cyclic AMP-dependent and -independent adrenal steroidogenesis in rats. Fournal of Molecular Endocrinology 1 147-154.
Stocco DM \& Clark BJ 1996 Regulation of the acute production of steroids in steroidogenic cells. Endocrine Reviews 17 221-244.

Svensson LT, Endberg ST, Aoyama T, Usuda N, Alexon SEH \& Hashimoto T 1998 Molecular cloning and characterization of a mitochondrial peroxisome proliferator-induced acyl-CoA thioestease from rata liver. Biochemical fournal 329 601-608.

Tomoda H, Igarashi K \& Omura S 1987 Inhibition of acyl-CoA synthetase by triacsins. Biochimica et Biophysica Acta 921 595-598.

Towbin H, Stachelin T \& Gordon J 1979 Electrophoretic transfer of proteins from polyacrylamide gels to nitrocellulose sheets procedure and some applications. PNAS 76 4350-4354.

Wang X, Walsh LP, Reinhart AJ \& Stocco DM 2000 The role of arachidonic acid in steroidogenesis and steroidogenic acute regulatory (StAR) gene and protein expression. Fournal of Biological Chemistry $27520204-20209$.

Received 16 March 2005

Accepted 18 March 2005

Made available online as an Accepted Preprint 31 March 2005 